\title{
WOODLOT MANAGEMENT PROMOTION BY THE C.I.F. IN 1951
}

\author{
BY J. L. VAN CAMPI \\ INTRODUCTION
}

Canada's professional foresters, assembled at Sault Ste. Marie, Ontario, in October, 1950, for their first annual meeting as the Canadian Institute of Forestry, unanimously adopted a resolution to concentrate attention on woodlot management in 1951. The machinery for this concentration of effort was centred in a promotion committee. As was fitting, this group was created as a sub-committee of the Standing Committee on Woodlot Management, one of the long-time champions of better forest management on privately-owned lands.

Two specific items may be said to have prompted the establishment of the Woodlot Management Promotion Committee for 1951. The first of these was an article "Woodlot Management Promotion" in the September, 1950, Forestry Chronicle. This paper and its logical successor, "Action Needed for Woodlot Management Promotion" were authored by Alex M. Koroleff, a forester with many years active campaigning for woodlot management to his credit.

\section{HISTORY}

The Canadian Institute of Forestry was not facing an unknown issue in accepting the responsibility of promoting better woodlot management. By letter ballot in January 1943, the members (then known as the C.S.F.E.) approved a statement of Forest Policy including the following points:-

7. 'Private owners of forests are responsible for maintaining their true forest lands in a productive condition, both in their own interest and in that of the community. Owners of farm woodlots constitute a particularly important section of this group.

37. The farm woodlot is capable of highly profitable development, not only to the farmer but as an integral part of the nation's wood supply. Governments should assist farmers to improve their woodlots through educational means, provision of demonstration forests, technical advice, and supply of planting stock. Effective protection of woodlots should be organized in each municipality, preferably under government supervision. ${ }^{2}$

64. Special courses of training in the management of farm woodlots and the proper utilization of forest products should be made available to farmers and their sons'.

In addition to policy statements and other paper programs, necessary in themselves, there is also in Canada a long record of professional service in the management of privately-owned forest lands. Members of government departments, the forest industries and associations, and foresters in private employment have all contributed effectively to this work. By every means available to them they have demonstrated the value of perpetual crops of wood from the same acre. Resultant benefits in soil, water and wild-life conservation, and the recreational and aesthetic values inherent in good woods management for an area have had their place in the literature and lecture work of foresters and their supporters in every province.

1. General Manager, Canadian Forestry Association, Montreal, and Chairman, Woodlot Promotion Committee, Canadign Institute of Forestry.

2. The last four words might better read "with the cooperation of the government." 
By virtue of our comparative youth as a nation, many of the first advocates of woodlot management are still active as educators of the public. Others have joined the ranks during the past quarter century, and more recently with rising public interest and more trained personnel available the number of workers assisting woodlot owners has shown a marked upturn.

Using but a few names may earn well merited reproach for omitting others equally deserving. However, to give point to the record we may well remember and list the contributions made by some men, recognizing that a full history would require a bulky volume, one which might well be written.

Fernow, Howe, Lotbinière, Wm. Little and Elihu Stewart are memories. Ellwood Wilson is today an active woodland management worker in Quebec's Eastern Townships, where his presence has been felt since 1907. E. J. Zavitz in Ontario has a similarly enviable record, matched by only a few others on the North American continent. Long service to woodlot owners calls to mind I. C. Marritt in Ontario, Roch Delisle in Quebec and Nelson Adams in New Brunswick. W. M. Robertson and George Mulloy served likewise under Dominion auspices. Recommendations for woodlot betterment were proposed by the Royal Commissioners-Sloan in B.C. and Kennedy in Ontario. There have been other important studies in Saskatchewan, Ontario and New Brunswick.

Close association with the actual owner of woodland is most effective, and here the "zone" foresters of provincial departments are making definite impact. Even with administrative promotion, and thus with less tangible field contacts, the foresters who have worked in the woods with private owners retain their enthusiasm for this activity. The fraternity of woodland managers has a kinship which extends across provincial and even international lines. It bridges the gulf which sometimes separates the foresters in industry from those in the public service. Today progressive forest industries and trade associations are setting a fast pace in bringing woods management assistance to woods owners and operators. The seedling is becoming a promising sapling.

The NATIONAL W.M.P.C.

While it is essential to have guidance and leadership from foresters on technical problems, it is likewise imperative that the general public be fully informed and convinced, for support of effective action. This again has long been realized in forest conservation. The pertinent quotation in the Forest Policy statement of 1943 under 9 (a) and 60 is as follows:-

9 (a) "The fostering of an intelligent and permanent public interest in the wise use of the forest resources is the greatest need of forestry in Canada.

60 The development of an informed public interest in the wise use of the forest resource is the greatest need of forestry in Canada. Without effective public support a satisfactory rate of progress is impossible'.

To this end the membership of the national W.M.P.C. was made up to include, as widely as possible, men from government and industry, trade associations and labor unions, the church, schools and colleges, farm groups, leaders in press and radio, and those in Canada and in the neighbouring States with woodlot management experience. While the membership attempted did reach many fis: 
interests, the list could be greatly extended, with profit. Only the difficulty of assembling busy people from the enormous country that is Canada restricts the formation of a truly representative central committee. The preponderance of members from the headquarters area is thus expedient rather than ideal, but compensation is achieved by local sub-committee membership.

Active members of the National committee include the following C.I.F. members:
Nelson Adams
K. G. Fensom
G. W. I. Creighton
A. Bickerstaff
N. Kastrukoff
I. C. Marritt
E. S. Fellows
D. V. Love
D. E. Nickerson
Geo. R. Hopping
D. M. Trew
W. E. Steele
A. M. Koroleff
J. P. Nicol
Dr. R. E. Balch
W. A. E. Pepler
Roch Delisle
J. B. Matthews
M. R. Wilson
J. D. Gilmour
M. N. Palley
R. G. Belcher
Maj.-Gen. Howard Kennedy

Their contributions have been reported in three sets of minutes of the national committee. In addition, circular letters have been used when further suggestions were found worthy of report to the committee, and its large supplementary mailing list.

\section{C.I.F. Actions Assisted by the National Committee}

\section{C.I.F. Standing Committee}

Several of the standing committees of the Canadian Institute of Forestry are integrating their normal activities into the increased emphasis of the Institute on the promotion of woodlot management. Conspicuous among these are the committees on Taxation and Legislation, Silviculture, Forest Entomology and Surveys.

The Standing Committee on Surveys, through its Chairman, H. E. Seely, of the Forestry Branch, Department of Resources and Development, Ottawa, made a number of practical suggestions to the Promotion Committee. One of these relates directly to an obvious weakness in the Woodlot Management programme, namely the lack of basic survey or other statistical data, on the extent, distribution and composition of woodlots in Canada.

The Chief Conservationist of the Ontario Department of Planning and Development, A. H. Richardson, pointed out that this situation was not true for all of Ontario. Here perhaps the most complete data on woodlots has been gathered for any portion of Canada during the past several years. This information is in the files of the Department and in published reports, and was obtained from intensive surveys conducted under the Conservation Authorities Act, operating under thirteen separate units. Information on woodlots is thus available for a considerable portion of the settled part of Southern Ontario.

The situation is still unsatisfactory from the basic data standpoint for much of the rest of Canada, even in the older settled portions such as the Maritimes and the Eastern Townships of Quebec.

Seely has suggested that the Canada Forestry Act, which came into effect during 1950, may help to provide much of this missing information. Agreements are already being prepared with a number of Provincial Departments of 
Lands and Forests, in cooperation with the Forestry Branch, for the completion of forest surveys of an inventory type.

It has been suggested that when these agreements are consumated, it would be advisable for the Woodlot Promotion Committee (or its sub-committees in the various sections of the C.I.F.) to work in close cooperation with Provincial Governments. Basic inventory data on privately-owned lands, woodlots located on these lands, and areas of waste land which should be reforested or otherwise returned to forest production should be included in the total shown. The production of continuous crops of forest products from every acre of privately-owned forest type land is the goal in the long range programme of woodlot management for the country as a whole.

Actions of standing committees in assisting the woodlot management programme will be reported in detail in their reports, submitted at the annual meeting of the Institute in October, 1951. The request of the President that this subject be clearly kept in mind in the regular work of the standing committees, and so reported that the total contribution will be visible to the Institute, is being acted upon by these groups across the country.

Action by the Section Committees on Woodlot Management Promotion

Reports of the various Section sub-committees on woodlot management promotion show the wide diversity of problems encountered in this phase of forest management.

An early report was received from Newfoundland, where studies are being conducted by research foresters of the Forestry Branch of the Department of Resources and Development. Interesting comments descriptive of the situation in Newfoundland, Ontario, British Columbia and elsewhere in Canada are included in articles in this issue of "The Forestry Chronicle."

In the prairie provinces woodlot management on private lands is concentrated in the fringe of partially wooded territory between the open prairies and the provincially owned and operated timber areas of the north or west. Here the situation is in a state of transition, with some timber land still being cleared for agricultural use by new settlers.

The question of accurate analysis of these areas from the land use standpoint is still debatable. In the opinion of many foresters much land has been classified as suitable for clearing and agricultural use which will sooner or later be abandoned, or revert to forest type land from which it should never have been removed. While Provincial Departments of Lands and Forests and the Agricultural Departments or Departments of Colonization are making an honest attempt to classify lands before they are opened to settlement, shortage of personnel, lack of knowledge of what constitutes true forest soils, and population pressure in certain areas is causing timber to be cleared from the same types of soil which have already been abandoned in similar areas not far distant.

All three of the Prairie Provinces are conscious of these problems, and in some cases are making special studies with the assistance of consulting foresters, plus detailed surveys conducted by their Departmental staffs. In Alberta a definite proportion of homestead land must be retained in timber cover by provincial 
law. However, fires escaping from brush burning operations in connection with land clearing have caused extensive damage in this and other Western Provinces. This further complicates the question of woodlot management, since adequate protection is at the base of any system of good management of forest lands.

In Northern Ontario areas of settlement are comparatively small in comparison with the vast acreages operated by the forest industries on Crown lands. As a result the problem of woodlots in private ownership is not given top priority.

Because of this O. R. Evans, Agricultural Editor of the Montreal Family Herald and Weekly Star suggested that a letter from the Committee might be in order, pointing out the importance of these problems, and the need for their solution in the area covered by the Northern Ontario Section of the Canadian Institute of Forestry. The proposed letter was written to the Chairman of the Section and acknowledged by him.

Special Chronicle Issue

The present issue of the Chronicle is a specific item of assistance to Woodlot Management Promotion. The Editor has had many suggestions for articles, due to the wide range of items involved. However, due to space restrictions, the coverage has been necessarily selective, with due considerations for geography, and for representative items from private, industrial, association and govenment workers.

Annual Meeting of the C.I.F. at Banff in October, 1951

While the theme of the 1951 annual meeting is Multiple Use of Forests, Dr. George R. Hopping and the Steering Committee have given almost one full day to the discussion of woodlot management. During the first half-day session there will be reports of Woodlot Management Promotion Committees, and general discussion on these activities. Definite proposals for the continuation of woodlot management activities in 1952 will be presented, and ways and means to put these recommendations into actual practice will be proposed at the final session.

The meeting at Banff will naturally be attended chiefly by foresters from that area. This means that a smaller percentage of people interested in woodlot management will be in attendance than would have been the case in a more easterly location. However, if the term woodlot is taken in its widest sense then the question will have sufficient importance to justify careful consideration by foresters from the Western provinces. In addition, foresters from the older settled portions of the country, concerned with the continuing pogrammes of woodlot management in agricultural areas, or bordering these lands, will be actively engaged in the woodlot sessions.

ACTION IN COOPERATION WITH OTHER ORGaNIZATIONS

Chambers of Commerce

One of the first groups to volunteer assistance in connection with woodlot management promotion was the Canadian Chamber of Commerce, through its field representative, Evan McCormick. W. A. E. Pepler, Manager of the Woodlands Section of the Canadian Pulp and Paper Association suggested that more foresters should be making public addresses before service clubs and 
other organized groups. Mr. McCormick was asked whether or not his organization would be interested in obtaining speakers for Chambers of Commerce across the country. Following his positive response, permission was obtained from the Chairman of the C.I.F. to have the Chamber of Commerce contact Section Secretaries for speakers on Forestry subjects.

While this activity did not begin early enough in the season for full participation by a large number of service groups some excellent contacts were made. A number of foresters spoke to Chambers of Commerce, Rotary and other groups in their territories.

It is planned to remind the Chamber of Commerce secretaries to contact the Section Secretaries once again, so that speakers may be obtained throughout the winter months. This is a season when foresters are more readily available for indoor meetings, than when they are occupied by Fire Prevention, Timber Management, and other field activities which might hinder the acceptance of public speaking engagements.

Brotberbood of Pulp, Paper and Sulphite Workers

Another excellent contact made through the Committee was the Educational Director of the Brotherhood of Pulp, Paper and Sulphite Workers, James Nicol, who has headquarters in Montreal.

For a number of years Mr. Nicol has prepared a weekly information sheet, mimeographed and distributed to a large mailing list in the membership of his union. These bulletins contained information on general economic conditions, or on the specific problems of the worker, the local chapter, or the union, in connection with the industry and in relation to current economic situations.

Mr. Nicol had long felt that the workers in the forest industry are concerned with the forest resource on which their livelihood depends. He was therefore interested in obtaining background material for a forestry information sheet which he prepared and distributed to the mailing list within his oganization. Copies of this mimeographed circular were obtained from Mr. Nicol and circulated to the membership and mailing list of the Committee on Woodlot Management Promotion, as a suggestion for an activity which might be applied within their own organizations.

The response to the Forestry circular was so favourable that Mr. Nicol prepared a second publication entitled 'The Forestry Night Progamme'. This proposed a cooperative meeting between the local union and service organizations in town, such as the Chamber of Commerce, Board of Trade or others interested in the welfare of the community. Detailed programmes were given for 'The Forestry Night', at which motion pictures, talks, exhibits or displays of local Forest Industry and Forest Resource material might be displayed and discussed by the members and their guests.

A number of the units organized and operated these Forestry Nights in cooperation with civic groups and found them very successful in creating wider interest in the forest and in its management. Closer cooperation between the members of the brotherhood, and other groups concerned with the maintenance of the forestry industry for the livelihood of the community was achieved at these meetings. 
Co-operation with School Boards

Specific examples were reported of cooperation between committees of the Sections of the C.I.F. and local school boards for the practical education of pupils in some phase of woodlot management.

Near Fort William, the Slate River School district was assisted by the Foresters of that area in reforestation of a half acre of ground, purchased by the School Boad to be maintained permanently as a school forest.

This project is to be continued in succeeding years until at least the five acres now owned is reforested, with trees furnished by the Ontario Department of Lands and Forests. By this means, each succeeding group of students in the Slate River School will have a practical demonstration of tree planting. They will also see the benefits of reforesting waste land for production of timber crops, under the direction of members of the Canadian Institute of Forestry.

A similar project in the Maritimes has been operated for a number of years. The practical development of school forests in cooperation with the Canadian Institute of Forestry is one tangible evidence of the teaching of woodlot management which will have permanent and continuing results wherever this means is adopted.

Farm Forums and other Programmes on C.B.C.

One of the topics adopted for discussion by the Farm Forums was "The Farm Woodlot". Background material for this discussion was prepared in cooperation with the Chairman of the Woodlot Management Promotion Committee.

The National summary shows that many thousands of farm people took part in these discussions or listened in their homes. The questionnaire prepared following this broadcast have been summarized, and were distributed to members of the committee as an indication of the interest and the concern of farm people on problems of woodlot management, including conservation, marketing and other features of this problem.

The Canadian Broadcasting Corporation assisted in other radio programmes in connection with Farm Woodlot Management, after consultation with members of the committee. A series running during the present summer each Monday evening is entitled 'Don't Destroy'. Seven fifteen-minute programmes over the National hookup will be given during the summer, each one well dramatized and reaching a large listening audience.

The Canadian Forestry Association

The fact that the Secretary of the Promotion Committee is also General Manager of the Canadian Forestry Association guarantees a considerable proportion of the time of the Canadian Forestry Association being devoted to woodlot management promotion. It has also been felt for some time that in addition to the basic and necessary protection campaigns of the Association, it is important to encourage good management wherever possible. This is a positive programme which can show definite results, in contrast to protection programmes, which by their very nature are largely negative in character.

Following a number of meetings with the Woodlot Programme Committee of the Woodlands Section, Canadian Pulp and Paper Association, the Executive Committee of the Canadian Forestry Association voted to devote fifty per cent 
of its time and money to the Promotion of Woodlot Management as rapidly as this change in emphasis can be accomplished within the Association. With this directive, the work of the Woodlot Management Promotion Committee has been kept well to the forefront of Association activities, and close cooperation is being developed with all organizations having similar objectives.

The Canadian Federation of Agriculture

The presence of R. A. Stewart of Almonte on the committee, has maintained a close contact with the Canadian Federation of Agriculture, of which Mr. Stewart was president for Ontario in 1951.

Cooperation with agricultural agencies is so desirable that it would justify an entire committee for this purpose. So much of the success of woodlot management activities depends on the full understanding and cooperation of people in agriculture, from the farm owner, the key man in the entire problem, to the Educational Institutions. Agricultural leaders at present receive little or no instruction in woods problems during their professional training. As a result agricultural organizations give timber and woods problems scant attention, even in heavily timbeed areas.

\section{Ontario Conservation Association}

An influential organization, including the reeves and other strategically placed citizens interested in conservation, the O.C.A. (until recently known as the Ontario Conservation and Reforestation Association), has worked for many years on woodlot problems. A number of legislative tax and educational advances are listed to their credit.

The Committee has worked closely with the O.C.A. on rural fire prevention, assessment charges and more recently, on prevention of woodlot pasturing by livestock. Watson Porter, Editor of The Farmers Advocate, and W. E. Steele, District Forester of the Ontario Department of Lands and Forests have been most zealous in these programmes. County and township groups provide case histories of woodlot problems, and also lead in programs of protection, with a start toward management, cooperative marketing and other desirable activities.

\section{Forest Products Industries Associations}

The industry sponsored associations have a strong interest in privately owned forest lands because of the volume of wood products grown and cut on these areas. Educational work is carried on with owners, jobbers and woods labour, in an effort to maintain this source of wood. Industry is realizing the great importance of a proper attitude by the buyer toward sustained yield and good woodlot management. The Woodlands Section, C.P. \& P.A., is a leading member of the Industry associations.

Association newsletters and bulletins have carried woodlot management information to the sawmill and the pulp and paper companies, many of whom have used this data in their own house organs. T. S. Jones, of the Thunder Bay Timber Operators Association has used most effective publicity means. Editorials and articles in "Timber of Canada" have also been valuable.

Cooperation with U.S. groups

To benefit by the experience in woodlot management from the States ad- 
joining the International boundary, assistance was sought and received from extension foresters and forestry associations in New Hampshire, Pennsylvania, New York and Indiana. The Extension Forester for New Hampshire, K. E. Barraclough, brought a new woodlot management motion picture to Montreal for the Committee to inspect. This film, entitled "Wooden Dollars from New Hampshire Forests" was prepared in cooperation with the Society for the Protection of New Hampshire Forests. The farm woodlot programme is well depicted in this sound and color motion picture.

Correspondence with the director of the A.F.P.I., Charles Gillett, and with S. L. Frost, Executive Director of the American Forestry Association, has provided helpful direction, especially in developing means of stimulating group action in support of woodlot management. While many U.S. and Canadian conditions are diverse, the problems involved in the management of small units of privately owned timber land are remarkably alike in both countries. The human element is very similar, and in both countries the great potential of production from these areas is far from realization.

\section{CONCLUSION}

It is perhaps well to conclude this brief survey of one season's effort by the national professional society on a note of the magnitude of the task ahead. Casual reading might convey the impression that many hands have made light labor of woodlot management. Perhaps it would be more accurate to say that the patient has been well treated by those in attendance, but his recovery is much too slow. An eyedropper is being used when a two-inch stream under $100 \mathrm{lbs}$. pressure is required.

The attention concentrated upon woodlot management in 1951 has shown the interest, the activities, and the accomplishments of foresters, owners and laymen. The achievements ahead should include much more-good land use; equitable taxation, local, provincial and federal; adequate protection from fire, grazing, diseases and insects, and especially from destructive over-cutting. Wood capital must be built up in most areas. Owner education in marketing, home use and recognition of woodlot values is urgently needed. These changes, which will be aided greatly by a well-informed public, are goals to be sought consistently and zealously by the foresters of Canada. Sound policy statements point the course, but it takes forward driving action to reach the objectives we have set ourselves. 